\title{
Host-specific pit-forming epizoans on Silurian crinoids
}

\author{
CARLTON E. BRETT
}

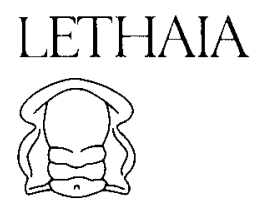

\begin{abstract}
Brett, Carlton E. 197807 15: Host-specific pit-forming epizoans on Silurian crinoids. Lethaia, Vol. 11. pp. 217-232. Oslo. ISSN 0024-1164.

Circular-parabolic pits occur commonly on the endoskeletal remains of certain Paleozoic crinoids. Detailed study of several hundred specimens, representing about 30 pelmatozoan species from the Upper Silurian Rochester Shale of New York and Ontario, reveals that such pits occur exclusively in seven species of crinoids. Furthermore, there are consistent differences in the morphology and orientation of holes occurring on the different crinoid species. This suggests that distinct epizoan species settled selectively on given hosts. The relationship between the hole-producing epizoans and crinoid hosts is inferred to have been a form of dependent commensalism. Preliminary surveys of other Paleozoic crinoid assemblages reveal similar host-selectivity by pit-producing epizoans. Crinoidepizoan pairs apparently co-evolved through considerable spans of geologic time as related genera and species of different ages, from Silurian to Pennsylvanian, exhibit similar pits.
\end{abstract}

Carlton E. Brett, Museum of Paleontology, University of Michigan, Ann Arbor, Michigan 48109. U.S.A.; 25th May, 1977 (revised 25th November, 1977).

Many examples of host-specific symbiotic relationships between invertebrate organisms have been documented in modern marine communities (Dales 1957; Hopkins 1957; Yonge 1957). Presumably, these pairs reflect long periods of co-evolution between host and symbiont lineages. Although evidence of close relationships between organisms is frequently preserved in the fossil record, relatively few detailed studies have attempted to trace host-specific relationships between ancient organisms (Bowsher 1955; Richards 1974; and Thayer 1974 are notable exceptions).

Unlike the inert exoskeletons of many invertebrates the endoskeletal plates of echinoderms are permeated with living stroma tissue, including cells which not only produce primary plate growth but are also capable of considerable secondary modification (Raup 1966; Macurda \& Meyer 1974). Not only are the skeletal plates of echinoderms exposed to colonization by epizoans, they are capable of responding to environmental stimuli such as the presence of attached organisms.

The occurrence of various deformations and borings in fossil crinoid stems and calyces has long attracted the attention of paleontologists and biologists (Etheridge 1880; Graff 1885; Moodie 1918). In the past, most authors have directed attention toward determining the causative agent of the various deformations (Graff 1884, 1885; Warn 1974; Franzén 1974; Welch 1976). However, certain indirect evidence bearing on the behavior and mode of life of the deformation-producing epizoans and their relationship to the crinoid hosts has been overlooked.

Franzén (1974) has surveyed and classified deformations in Silurian and Devonian crinoids including circular parabolic pits which she implies were the work of epizoans (foraminiferans) that settled unselectively upon various crinoids. Such a relationship should be reflected in the fossil record by a random distribution of pits among various crinoid species. Thus, pits should be expected to occur more frequently on the most abundant, or largest members of crinoid assemblages, which therefore presented the greatest surface area to settling epizoans. Previous authors provide no data on the distribution of pits or 'borings' among different species of crinoids which would be pertinent to the verification of this hypothesis. However, studies by the author demonstrate that the distribution of parabolic pits, at least in certain fossil crinoid assemblages, is not random but highly selective.

\section{Review of previous studies and terminology}

A variety of quite dissimilar deformations occur in fossil crinoids. These were probably induced by several very different epizoan agents. At least seven morphologically distinctive types of 


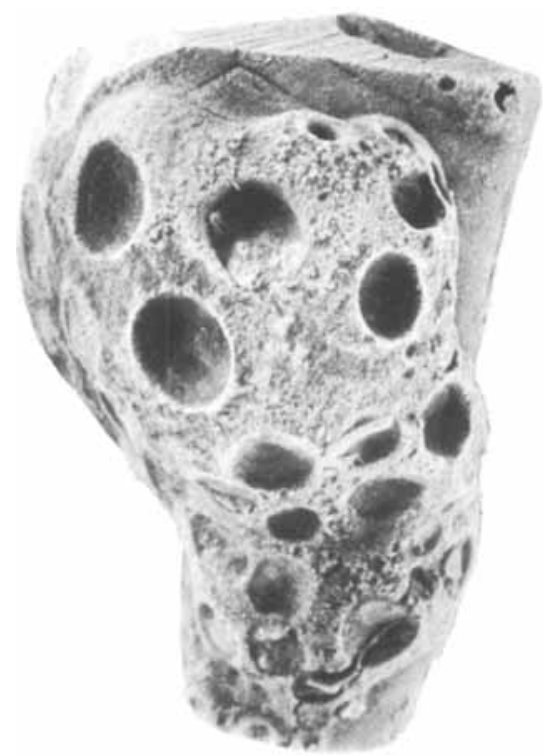

Fig. I. Crinoid column exhibiting extreme deformation caused by pit-forming epizoans. Circular parabolic pits are embedded in gall-like swellings of stereom; resembles type of 'Myzostomites' clarkei Howell, 1962. Rochester Shale. Thrall Road cut near Cambria, Niagara Co., N.Y. BMS E23975: $\times 5$.

deformations can be recognized in Paleozoic crinoids, as follows: (1) irregular swellings of excess stereomic secretion and warping of plate sutures caused by the attachment of nonsymbiotic organisms, such as auloporid corals, bryozoans, or other crinoids, to crinoid stems (Etheridge 1880; Franzén 1974, Figs. 11, 12); (2) cysts of true myzostomid parasites on crinoid arms (Welch 1976, Fig. 2); (3) paired holes, termed Schizoproboscina, occurring on the arms of some Carboniferous crinoids (Yakovlev 1939; Arendt 1961); (4) galls on crinoid columns, produced by Phosphannulus-bearing organisms (Warn 1974; Welch 1976); (5) barrel-like swellings and oval perforations of the column associated with ring-like tubes around the axial canal of crinoid columns (Franzén 1974, Fig. 10); (6) indiscriminately positioned pits of boring epizoans such as acrothoracican barnacles, bryozoans, or sponges, without associated deformation (Häntzschel 1975); and (7) circular-parabolic pits, with or without associated swellings, found on crinoid stems, calyx plates and arms (J. M. Clarke 1908, 1921; Girty 1915; Moore \& Plummer
1940; Strimple 1963; Branson 1964; Franzén 1974; see Fig. 1 herein).

The seventh category listed above probably constitutes the most abundant and most frequently described type of deformation. Those deformations in fossil crinoids discussed in the present paper belong entirely to this group (Types 1 and 2 of Franzén). Although, as pointed out below, slight variations exist in the morphology of pits occurring in different species of crinoids, all are circular in outline, generally parabolic in cross section, tapering inward, and are oriented perpendicularly to exterior surfaces of crinoid plates (Fig. 4C). Pits occur both in crowns and in columns of crinoids. Their occurrence in both of these portions of single individuals indicates that all of the pits were probably produced by the same epizoan type. However, the nature of the associated deformation differs slightly in the two regions.

Apparently growths of excess stereom formed readily in crinoid columns in response to irritations (Fig. 1), whereas such growths of stereom formed only rarely in the calyx plates. These variations in deformation of skeletal material may reflect dissimilar histological responses of lime-secreting tissues in different portions of the crinoid. The stroma of the column, particularly in the dististele, was capable of varying rates of stereom secretion in response to environmental stimuli, as evidenced by the variable nature of holdfasts in different substrates (Ehrenberg 1929; Halleck 1973; Franzén 1977). On the other hand, rates of secretion by calyx stroma were probably more genetically fixed.

Differentiation between calyx and column deformations was noted by Girty (1915) who described swollen 'bored' columnals and undeformed 'bored' calyx plates from the Pennsylvanian of Oklahoma. This phenomenon is also illustrated in a specimen figured by Franzén (1974, Fig. 6) in which the column and proximal calyx portions of a crinoid are grotesquely deformed in the vicinity of the pits but the upper calyx and arms, though pitted, are undeformed.

Pits embedded in gall-like swellings, such as those illustrated in Fig. 1, have previously been placed in the ichnogenus Myzostomites (Häntzschel 1975). This designation is somewhat unfortunate as it suggests a relationship of the deformations on Paleozoic crinoid stems to those produced by the modern myzostomid annelids, for which there is very little evidence. Furthermore, the original definition of 
Myzostomites (Howell 1962) includes all swellings with a central perforation. As such, it applies well to deformations such as those described by Warn (1974) and Welch (1976) (category 4, above). However, the latter are fundamentally different from the deformed stem illustrated by Clarke (1921:59, Fig. 46) which has been designated as the genotype of Myzostomites (M. clarkei Howell, 1962). Clarke's figure depicts a crinoid stem possessing several circular-parabolic pits surrounded by a gall-like swelling. This specimen closely resembles deformed stems figured by Branson (1964), Franzén (1974), and herein (Fig. 1). However, perforated galls such as those described by Warn (1974) in Heterocrinus stems differ considerably from Clarke's specimen. The former are rather uniform in size, non-overlapping, often lead to internally expanded chambers, and are associated with phosphatic rings. In contrast, the latter show a wider size range, frequently overlap each other, and are invariably simple parabolic depressions with no associated rings. Clearly, the two types should be given separate designations as they are basically dissimilar.

Because of its misleading implications the term Myzostomites should probably be abandoned. In the present paper the non-taxonomic term 'circular-parabolic pits' (or simply 'pits') will be used to refer to deformations of category seven of the previous listing. Franzén (1974) presents convincing evidence that similar pits represent embedment structures (sensu Bromley 1970; see Korringa 1951; Cameron 1969; and Chatterton 1975 for additional examples). Therefore, the term 'pitted' is used in preference to 'bored'.

A primary objective of most previous studies of deformations in fossil crinoids has been the identification of causative agents. In some instances (e.g. Welch 1976) associated body fossils or close comparison with modern analogs provide fairly unequivocal clues. Franzén (1974) observed foraminiferan tests attached to the walls of circular-parabolic pits in Silurian crinoids. However, since these structures do not match the size of the holes and are not invariably associated with pits they may represent secondary occupants of vacated holes rather than producers of these depressions. Such tests were not observed in any of the parabolic pits examined by the author. Thus, the identity of the producers remains in doubt. This subject is not given further consideration in the present paper. The pit-producing organisms, whatever their identity, are referred to simply as epizoans.

\section{Host-specificity in crinoids from the Rochester Shale}

The Upper Silurian (Wenlockian) Rochester Shale in western New York and Ontario contains a diverse pelmatozoan fauna of crinoids, rhombiferan cystoids, and the problematical echinoderm Stephanocrinus (Bassler \& Moodey 1943). Discovery of abundant circular pits on certain crinoids, mainly Ichthyocrinus, from the Rochester Shale (Brett 1972) led to a systematic examination of several large museum and private collections of Rochester Shale echinoderms for additional examples of pitted calyces. A total sample of over three thousand pelmatozoan specimens from the Rochester has been examined in detail for the presence of parabolic pits. Such surveys - combined with field studies permit quantitative assessment of the distribution of parabolic pits among co-occurring crinoid taxa, and provide indirect evidence of the occurrence of the pit-producing epizoans in an ancient crinoid assemblage. Results of this study are summarized in Table 1.

Both crinoids and other pelmatozoan groups were considered in this study. However, despite relatively large samples (e.g. over 1000 thecae of Caryocrinites) no circular pits were observed in any non-crinoid specimens. The most abundantly represented echinoderm species in the lower Rochester Shale is Stephanocrinus angulatus Conrad. The classification of this problematical pelmatozoan is presently under study; it is very likely not a crinoid as has been previously stated (Fay 1962). No pits were observed among 1350 specimens of $S$. angulatus examined in detail.

About 25 species of camerate, inadunate, and flexible crinoids occur in the lower half of the Rochester Shale (personal observation). The occurrence of circular-parabolic pits appears to be restricted to seven of these forms. The most abundant species over-all are the flexible crinoid Lecanocrinus macropetalus Hall and the inadunate Calceocrinus chrysalis (Hall). Neither of these species was frequently infested by pitforming epizoans (Table 1). In marked contrast, certain co-occurring species, particularly Ichthyocrinus laevis Conrad (which ranks third 
Table 1. Occurrence of circular-parabolic pits on calyces of pelmatozoan echinoderms from the lower Rochester Shale (Upper Silurian; Wenlockian) of western New York and Ontario; data listed as ratio of the number of pitted individuals to total number of specimens of each species examined. Ratios are also expressed as percentages (within parentheses) to facilitate comparison among samples. Samples all derived from the lower 9 to $10 \mathrm{~m}$ of Rochester Shale. Symbols for samples as follows: $\square$ A. Homocrinus band, $5.2 \mathrm{~m}$ above base of formation at Lockport Gulf, Niagara Co., N.Y. $\square$ B. Undifferentiated lower half of formation at Lockport, N.Y. $\square$ C. Lower $3 \mathrm{~m}$ of shale at Niagara Gorge, south of Lewiston, Niagara Co., N.Y. $\square$ D. Shale 6 to $8 \mathrm{~m}$ above base of formation, Niagara Gorge, near Robert Moses Power Plant, Niagara Co., N.Y. $\square$ E. Undifferentiated lower third of formation at DeCew Falls, St. Catharines, Ontario.

\begin{tabular}{|c|c|c|c|c|c|c|c|c|c|c|}
\hline \multirow[t]{2}{*}{ Pelmatozoan species } & \multicolumn{10}{|c|}{ Samples } \\
\hline & A & & B & & $\mathrm{C}$ & & $\mathrm{D}$ & & $\mathbf{E}$ & \\
\hline \multicolumn{11}{|l|}{ Rhombifera } \\
\hline Apiocystites elegans Hall & - & & $0 / 15$ & $(0.0)$ & $0 / 3$ & $(0.0)$ & $0 / 5$ & $(0.0)$ & $0 / 4$ & $(0.0)$ \\
\hline Callocystites jewetti Hall & - & - & $0 / 13$ & $(0.0)$ & $0 / 2$ & $(0.0)$ & $0 / 3$ & $(0.0)$ & $0 / 8$ & $(0.0)$ \\
\hline Caryocrinites ornatus (Say) & $0 / 24$ & $(0.0)$ & $0 / 82$ & $(0.0)$ & $0 / 36$ & $(0.0)$ & $0 / 617$ & $(0.0)$ & $0 / 55$ & $(0.0)$ \\
\hline $\begin{array}{l}\text { 'Coronata' } \\
\text { Stephanocrinus angulatus Conrad }\end{array}$ & - & - & $0 / 108$ & $(0.0)$ & $0 / 537$ & $(0.0)$ & $0 / 105$ & $(0.0)$ & $0 / 112$ & $(0.0)$ \\
\hline \multicolumn{11}{|l|}{ Crinoidea } \\
\hline $\begin{array}{l}\text { Asaphocrinus ornatus (Hall) } \\
\text { Calceocrinus chrysalis (Hall) }\end{array}$ & $1 / 7 / 3$ & $\begin{array}{l}(23.3) \\
-\end{array}$ & $0 / 17^{-}$ & $(0.0)$ & $\begin{array}{l}3 / 15 \\
0 / 36\end{array}$ & $\begin{array}{r}(20.0) \\
(0.0)\end{array}$ & $0 / 12$ & $(0.0)$ & $\begin{array}{l}2 / 12 \\
0 / 52\end{array}$ & $\begin{array}{r}(16.6) \\
(0.0)\end{array}$ \\
\hline calceocrinid n.sp. & - & & $0 / 4$ & $(0.0)$ & $1 / 2$ & $(50.0)$ & - & & $1 / 5$ & $(20.0)$ \\
\hline Eucalyptocrinites caelatus (Hall) & - & - & $4 / 28$ & $(14.3)$ & $0 / 2$ & $(0.0)$ & $1 / 5$ & $(20.0)$ & $1 / 7$ & $(14.3)$ \\
\hline Homocrinus parvus Hall & $0 / 30$ & $(0.0)$ & - & - & - & - & - & - & $0 / 12$ & $(0.0)$ \\
\hline Ichthyocrinus laevis Conrad & $0 / 23$ & $(0.0)$ & $4 / 11$ & $(36.4)$ & - & - & $32 / 52$ & $(61.5)$ & $10 / 19$ & $(52.6)$ \\
\hline Lecanocrinus macropetalus Hall & $0 / 2$ & $(0.0)$ & $2 / 40$ & $(5.0)$ & $0 / 3$ & $(0.0)$ & $0 / 125$ & $(0.0)$ & $0 / 33$ & $(0.0)$ \\
\hline Lyriocrinus dactylus Hall & $0 / 7$ & $(0.0)$ & $0 / 8$ & $(0.0)$ & $0 / 2$ & $(0.0)$ & $0 / 9$ & $(0.0)$ & $0 / 5$ & $(0.0)$ \\
\hline Macrostylocrinus ornatus Hall & $0 / 15$ & $(0.0)$ & $0 / 2$ & $(0.0)$ & $0 / 8$ & $(0.0)$ & $0 / 3$ & $(0.0)$ & $0 / 5$ & $(0.0)$ \\
\hline Synchirocrinus? typus (R ingueberg) & - & & $3 / 19$ & $(15.8)$ & $5 / 9$ & $(55.5)$ & & & $0 / 6$ & $(0.0)$ \\
\hline others & $0 / 3$ & $(0.0)$ & $0 / 67$ & $(0.0)$ & $0 / 13$ & $(0.0)$ & $0 / 6$ & $(0.0)$ & $0 / 28$ & $(0.0)$ \\
\hline Totals & $17 / 177$ & $(9.6)$ & $13 / 414$ & (3.1) & $9 / 668$ & $(1.3)$ & $33 / 942$ & (3.5) & $14 / 363$ & (3.9) \\
\hline
\end{tabular}

in over-all abundance) were heavily pitted by epizoans (Table 1, Fig. 2). Among the less common species of crinoids (represented by 50 specimens or less) there is similar restriction of pits to a few species including Synchirocrinus? typus (Ringueberg) and an unidentified calceocrinid.

A statistical test for possible randomness of distribution of pits was performed, using data from collections of crinoids from the lower Rochester Shale. Specimens were counted as either 'pitted' - i.e. containing at least one circular pit - or 'non-pitted'; in total, 108 pitted specimens were observed. An attempt was made to sample and compare crinoids with similar calyx sizes. Certain species, i.e. Homocrinus parvus Hall and two myelodactylid crinoids, possessed extremely small calyces. These crinoids as well as extremely small (calyx height $<5 \mathrm{~mm}$ ) and very large (height $>25 \mathrm{~mm}$ ) specimens of other species were excluded from the counts. The remaining sample consists of crinoid species with roughly similar ranges of calyx size. Therefore, the crinoids utilized in the counts are thought to be approximately comparable in terms of total calyx surface area available for colonization by epizoans.

Assuming a random settlement pattern of the pit-forming epizoans, the frequency of infestation of a given crinoid species should be proportional to the relative abundance of individuals of that species in any particular community. With a Chi-square test, this null hypothesis can be rejected at greater than $99 \%$ probability.

Unfortunately, due to incomplete data on most museum specimens it was not generally possible to document large numbers of calyces from a single bedding plane and thus to prove that pitted and non-pitted specimens were contemporaneous. However, field observations on the distribution of fossils in the lower Rochester Shale indicate that nearly all of the species listed in Table 1 do co-occur. This supports the hypothesis that the epizoans were host-selective; this hypothesis is further supported by several instances of pitted and non-pitted crinoids cooccurring on single bedding planes.

One such example from the Rochester Shale is 


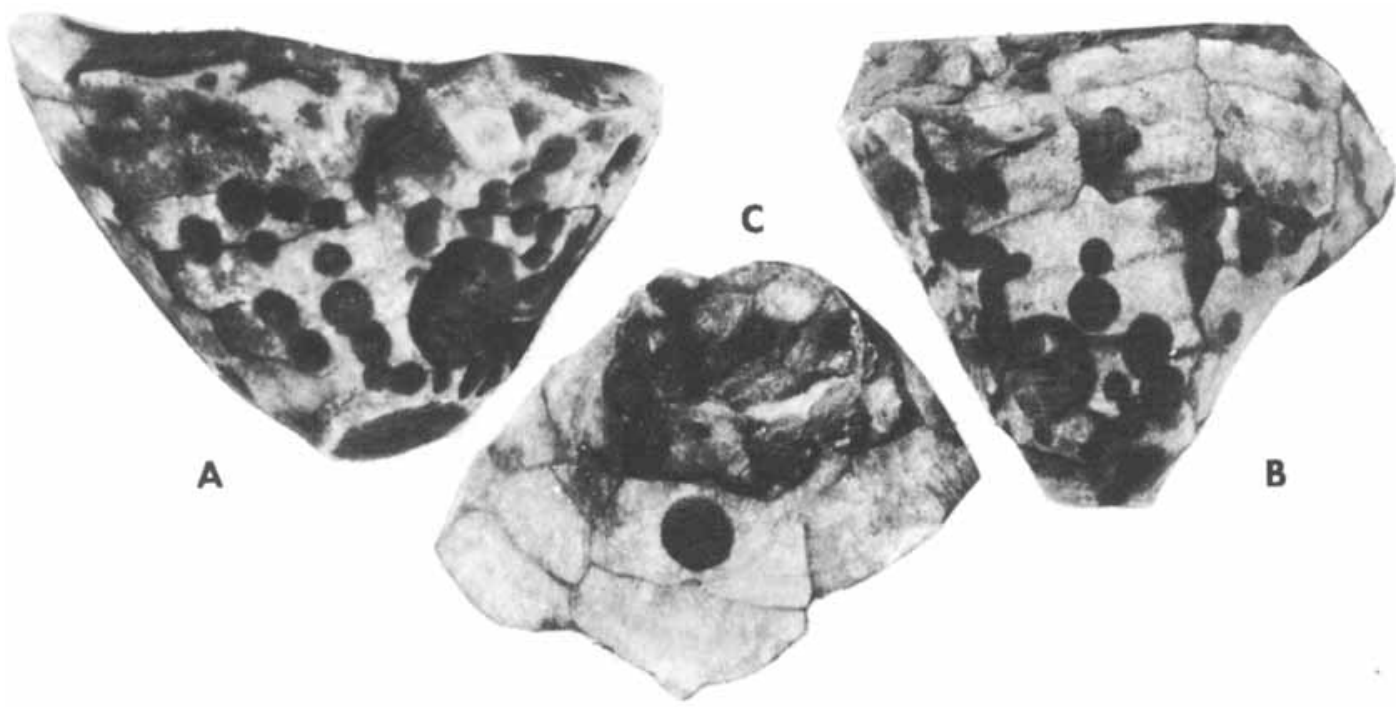

Fig. 2. Circular-parabolic pits in calyces of Ichthyocrinus laevis Conrad; Rochester Shale; Niagara Gorge, Lewiston, Niagara Co., N.Y. $\square$ A, B. Lateral views of calyces; note extensive riddling of plates by holes of varying size, frequent overlap of adjacent pits, and variable size of pits; BMS E23968, E23969. $\square$ C. Basal view of BMS E23970, exhibiting a ring of pits around the column cicatrix; note $2 \mathrm{~mm}$ hole centered on first primibrachial plate. All specimens $\times 3$.

provided by slabs containing well preserved crinoid and cystoid specimens in the Springer Collection, U.S. National Museum. Springer (1920) reports that these specimens were quarried from the Homocrinus bed, a horizon of well preserved fossils which occurs $5.2 \mathrm{~m}$ above the base of the Rochester Shale at Lockport, Niagara County, N.Y. (Ringueberg 1888). The very complete preservation of these fossils suggests that they represent the remains of a single community of crinoids (seven species), cystoids (one species), and other organisms, which was suddenly destroyed and buried. Pits were restricted to Asaphocrinus ornatus (Hall), occurring in 17 out of the total sample of 73 specimens. This proportion is of the same order of magnitude as those ratios obtained for two other collections of Asaphocrinus (Table 1), although the actual number of pitted individuals may be somewhat higher here since many individuals occur in slabs with only one side of the calyx visible. Although Ichthyocrinus laevis is commonly infested at other localities, none of the large number of individuals of Ichthyocrinus in the Homocrinus bed slabs shows pits. This will be discussed further below.

The species Eucalyptocrinites caelatus (Hall), as presently defined (Wachsmuth \& Springer 1897), includes forms with fine tuberculate orna- ment on the plates as well as relatively smoothplated individuals. Both types have been collected from the same beds. Thus far pits have been found only in the ornamented variety from the Rochester Shale (although not every ornate individual possesses the pits), again, suggesting host selection.

The high degree of host-selectivity is most dramatically illustrated in the calceocrinid crinoids. Certain horizons in the lower Rochester Shale at various localities in western New York and Ontario contain at least three different species of calceocrinids. Among these contemporaneous populations of calceocrinids, which were presumably adapted to similar recumbent life modes (Brower 1966), two species were selectively infested while the third, and usually more abundant form, Calceocrinus chrysalis, was uneffected (Table 1).

There is also evidence that different species of crinoids were hosts to different types (species?) of hole-forming epizoans. This evidence is derived from comparison of the morphology, distribution, and orientation of the pits and associated deformations on various Silurian crinoids. In the following sections, these characteristics of pits occurring on different crinoid species from the Rochester Shale are described in detail and compared. 

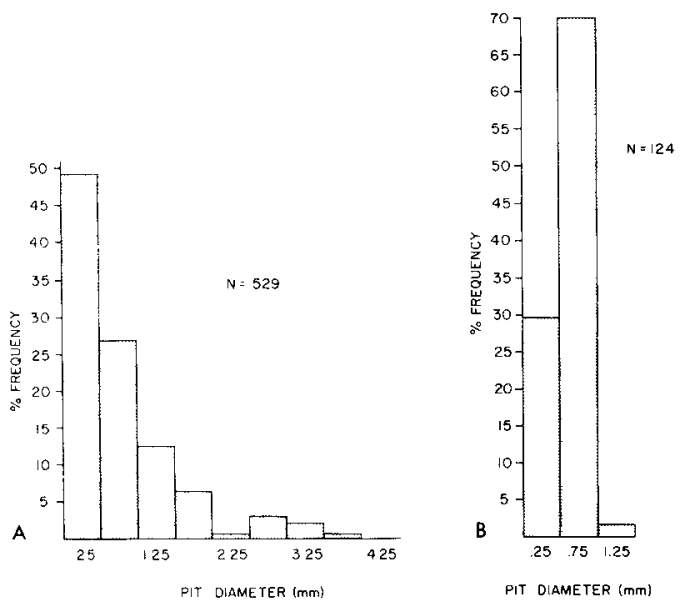

Fig. 3. Size-frequency histograms for diameters of circularparabolic pits in two species of crinoids. $\square$ A. Pits in Ichthyocrinus laevis Conrad; based on 529 pits measured in 15 calyces from Niagara Gorge, Niagara Co., N.Y.; note broad range. high percentage of minute pits. $\square$ B. Pits in Eucalyptocrinites caelatus (Hall); based on 124 measured pits in five calyces from western New York and Ontario; note much more restricted size range and extremely high percentage of $0.5-1.0 \mathrm{~mm}$ pits.

Type 1. - Host species: Ichthyocrinus laevis Conrad (Figs. 2-4). Circular pits occurring on Ichthyocrinus calyces from the Rochester Shale are regularly parabolic in cross section and about as deep (at maximum) as wide (depth/diameter $=$
$0.9)$. The holes exhibit a very broad range of diameters, from 0.1 to $3.6 \mathrm{~mm}$ (mean $=0.95 \mathrm{~mm}$; S.D. $=0.65$ ). A size-frequency histogram for pit diameters has been constructed on the basis of over 500 measured pits from a sample of 15 pitted calyces collected in approximately the same horizon, 5.5-6.0 $\mathrm{m}$ above the base of the Rochester Shale at Niagara Gorge (Fig. 3A). This sample is thought to approximate the relative frequencies of pits of various sizes in a population of co-occurring crinoids. The histogram reveals an over-all high frequency of minute pits $(<0.5 \mathrm{~mm})$.

Distribution of various sizes of pits is not uniform on individual calyces. Minute pits occur in extremely high numbers on some calyces (up to 80 per calyx), but they are completely absent from others (compare Figs. 2A and 2C). On the other hand, nearly every calyx observed to be pitted has at least one 3.0 to $3.5 \mathrm{~mm}$ hole. The maximum number of large pits observed on a single calyx is four. On several calyces, hole diameters exhibit a bimodal size-frequency distribution of numerous minute $(<0.5 \mathrm{~mm})$ and a few very large $(>3.0 \mathrm{~mm}$ ) holes (Fig. 2A). Considering the sample of pit diameters as a whole there is continuous gradation between all size categories, discrete grouping being restricted to individual calyces. The depth/diameter ratio and other morphological characteristics of the pits are fairly uniform in all sizes.
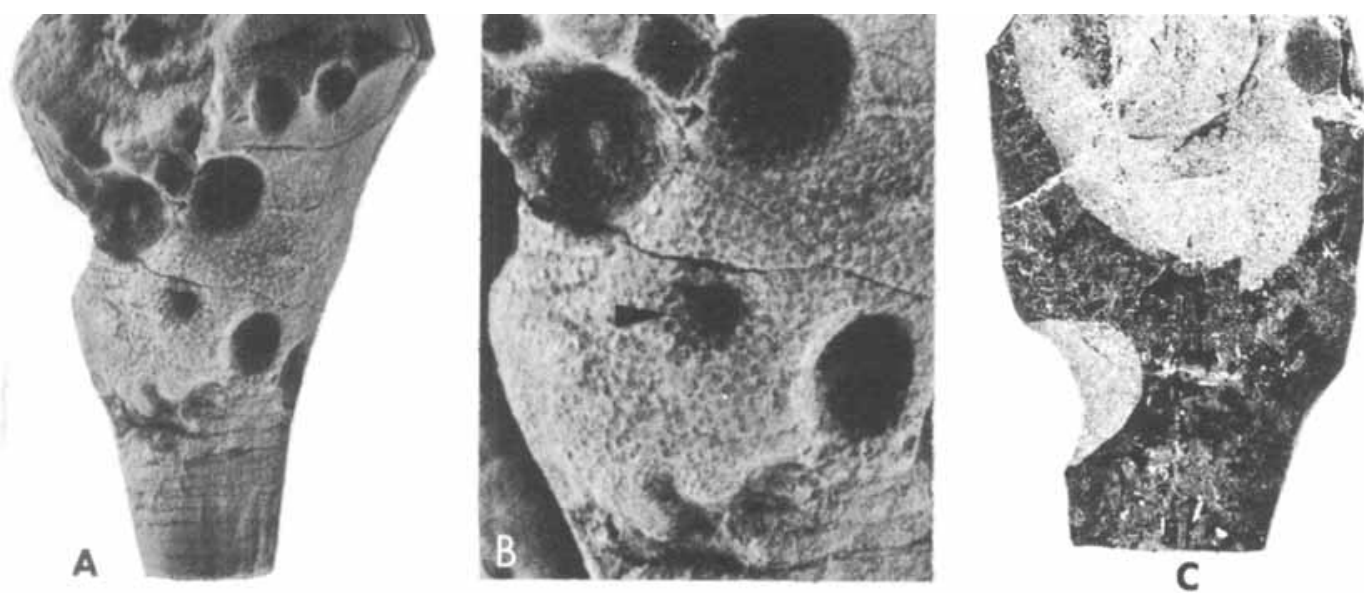

Fig. 4. Pits and associated deformations in Ichthyocrinus laevis Conrad; Rochester Shale; Niagara Gorge, Niagara Co., N.Y. $\square$ A. Calyx and proxistele of affected specimen exhibiting swelling in vicinity of pits; BMS E23971; $\times 3$. $\square$ B. Enlargement of basal area of specimen shown in A; small pit in center (arrow) has outer border blended; note reticulated character of swollen stereom which continues into floor of blended pit; $\times 6$. $\square$ C. Peel from cross section through pitted calyx; note that deep parabolic hole (maximum diameter $=3.2 \mathrm{~mm}$ ) does not penetrate into interior of calyx; BMS E23972; $\times 5$. 
Adjacent pits of all sizes occurring on Ichthyocrinus frequently overlap one another slightly. Observed overlap areas never constitute more than about $25 \%$ of the total area occupied by the two adjacent pits. In some cases chains or clusters of overlapping pits have removed a considerable volume of the crinoid plates (Fig. 2A, B). Frequently, one or two large holes are surrounded by numerous smaller pits (Fig. 2A).

The largest pits extend inward for about 3.2 to $3.4 \mathrm{~mm}$. The average thickness of Ichthyocrinus basal and radial plates is of the same order of magnitude; one would predict that some holes would penetrate the interior of the calyx. Serial grinding of pitted calyces has revealed this situation in two cases. However, the largest pits are usually located on the thickest portions of the calyx, near the column cicatrix. In this position the holes narrowly miss penetration into the visceral cavity of the crinoid (Fig. 4C).

Nearly all affected Ichthyocrinus specimens consist of dorsal cups lacking upper brachials. In every case, however, pits are concentrated near the base of the calyx. Pits become less frequent and usually smaller on successively higher brachial plates. The only known pitted crown possesses about 50 pits ranging from 0.5 to $4.0 \mathrm{~mm}$ in diameter on the cup below the first axillary plates. Only 12 holes, all less than $2.0 \mathrm{~mm}$ in diameter, occur on the secundibrachs, two minute $(0.5 \mathrm{~mm})$ pits on the tertibrachs, and none on higher parts of the arms.

About half the total number of pits observed in Ichthyocrinus cups occur on sutures between plates, which represent a very small proportion of the total surface area of the crinoid calyces. This suggests that sutures were favored settlement sites. Minute pits, in particular, are often aligned along sutures (Fig. 2A). In some cases pits form a ring around the column cicatrix (Fig. 2C). In contrast, some holes, including several of the largest, are centered on the midregions of plates.

Generally, there is little deformation of the plates associated with pits in Ichthyocrinus. Pits are never surrounded by rims or gall-like swellings as in some other crinoids (see below). However, in several specimens the base of the calyx and immediately adjacent column are slightly swollen in the affected area and some plates are noticeably thickened in the vicinity of the holes. In at least one case (Fig. 4A, B), the stereom in this swollen region bears a reticulate texture. Holes in this thickened region may have

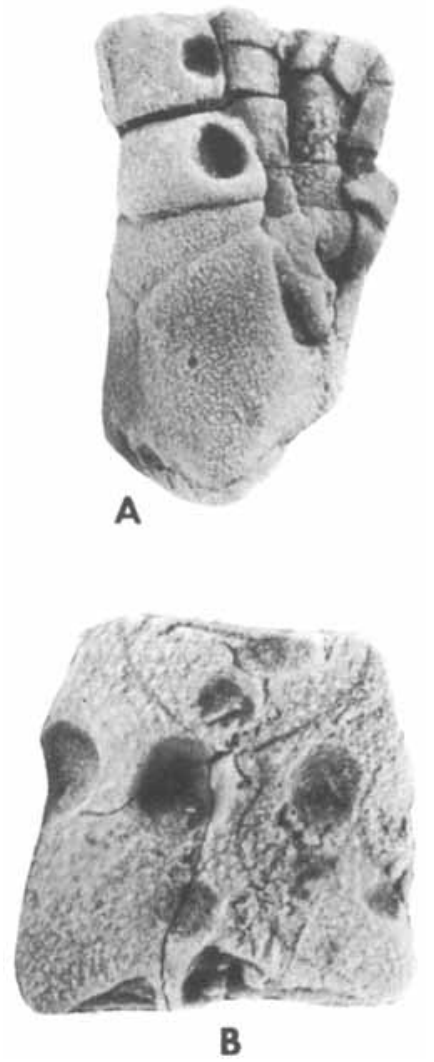

Fig. 5. Circular pits in calceocrinid crinoids. $\square$ A. Synchirocrinus? typus (Ringueberg); Rochester Shale, Niagara Gorge, Niagara Co., N.Y.; lateral (D-ray) view of partial crown; note holes in lower brachials of the large E-ray arm; BMS E23973; $\times 3$. $\square$ B. Undescribed species of calceocrinid; lower Rochester Shale, DeCew Falls, St. Catharines, Ontario; E-ray view of calyx exhibiting pits of varying size; ROM $35803 ; \times 6$.

been partially obliterated suggesting partial infilling of the pits by the crinoid's stereom.

Type 2. - Host species: Synchirocrinus? typus (Ringueberg) and other calceocrinid crinoids (Fig. 5). Pits occurring in calceocrinids closely resemble those in I. laevis in their morphology; i.e. they are deep, parabolic, circular in outline, and lack associated deformation. On the other hand, pits are much less numerous on any given calyx, the maximum number observed being 20 . The holes also show a more restricted size range $(0.5-2.0 \mathrm{~mm})$.

Very few minute pits $(<0.5 \mathrm{~mm})$ and no extremely large holes $(3.0-4.0 \mathrm{~mm})$ have been observed in calceocrinid crinoids. Pits tend to occur in clusters of three to five and frequent- 

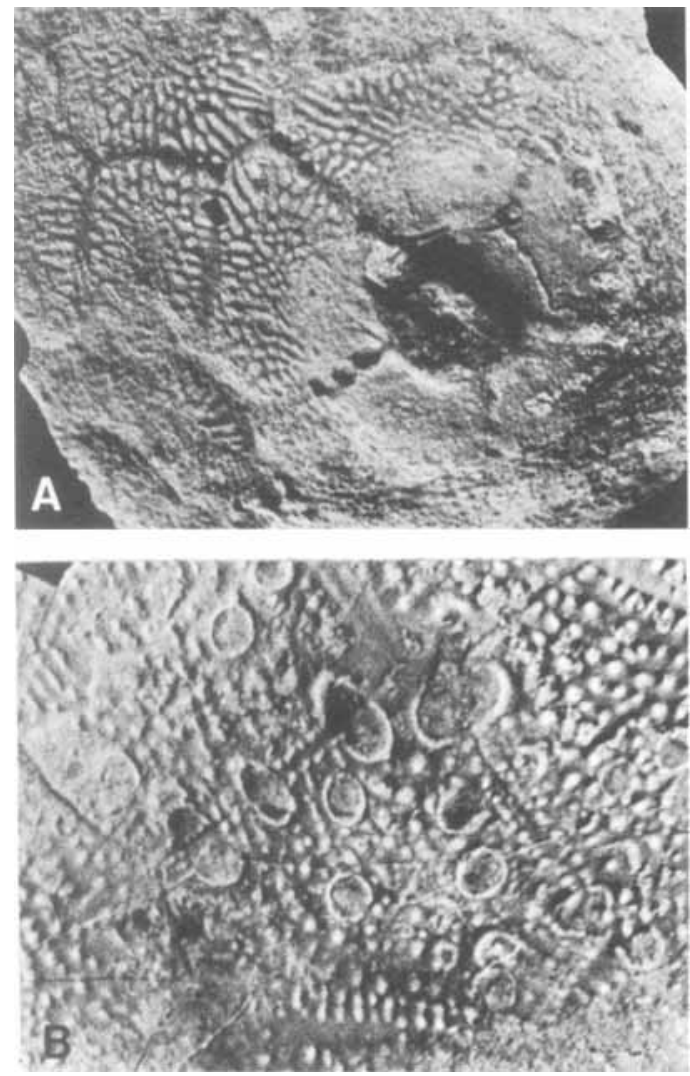

Fig. 6. Pits in Eucalyptocrinites. $\square$ A. Eucalyptocrinites cf. E. tuberculatus (Miller \& Dyer); Rochester Shale, dump piles at Thorold, Ontario; basal view of calyx exhibiting numerous small pits; note prominent alignment of pits along sutures; ROM $35809 ; \times 3$. $\square$ B. Eucalyptocrinites caelatus (Hall), holotype of Eucalyptocrinus papulosus Hall, 1852; Marshall's Mill, Salmon Creek, Sweden, Monroe Co., N.Y.; magnified portion of plate surface exhibiting typical surface ornament of granules, and circular pits surrounded by low rims of stereom: note elliptical outlines of three pits located along suture between two fixed brachial plates $\left(\mathrm{IBr}_{2}\right.$ and $\left.\mathrm{IIBr}_{1}\right)$; compare circular pits located elsewhere on the calyx; $\mathrm{AMNH}$ $1721 ; \times 4$.

ly overlap one another. The distribution of the parabolic pits in calceocrinids appears to be somewhat more random than in Ichthyocrinus. Pits have been observed in the basals, and the $A, D$, and $E$ radials as well as on the stout E-ray arm (Fig. 5A).

Type 3. - Host species: Eucalyptocrinites spp. (Figs. 3B, 6-8). Specimens of the camerate crinoids Eucalyptocrinites caelatus (Hall) and $E$. cf. E. tuberculatus (Miller \& Dyer) frequently exhibit numerous small, circular pits on the plate surfaces. On the whole, pits occurring in Eucalyptocrinites are much more uniform in size than those in Ichthyocrinus (Fig. 3B). Most specimens have numerous small holes of subequal size $(0.5-1.0 \mathrm{~mm}$; Figs. 6,7$)$. Pit diameters rarely exceed $1 \mathrm{~mm}$ and no holes in the $3.0-4.0$ $\mathrm{mm}$ range have been observed. Unlike pits occurring in all other species described herein, those in Eucalyptocrinites rarely overlap one another, and tend to be more evenly spaced over the surface of the calyx plates. Frequently the pits occur aligned along plate sutures (Fig. 6A).

In some cases such adsutural pits have been distorted into elliptical shapes (Fig. 6B) as a result of the accretionary plate growth. This phenomenon has not been observed in other pitted crinoids.

The holotype specimen of Eucalyptocrinus papulosus (Hall, 1852), a junior synonym of Eucalyptocrinites caelatus (Hall, 1852) (Wachsmuth \& Springer 1897), provides an outstanding example of a slightly different type of deformation which occurs in some specimens of Eucalyptocrinites (Fig. 6B). In his discussion of this supposed new species, Hall (1852:211) notes, as the diagnostic characteristic, the presence of 'round or oval depressions with raised margins, on the surface of the plates'. He further states that these pore-like orifices are indiscriminately scattered over the plate surfaces, sometimes near the plate sutures, sometimes at a distance from the margins.

Although the rimmed pits do not appear to be sunken as deeply into the plates as do other pits on Eucalyptocrinites, they otherwise exhibit the same morphology and size range as the latter. Furthermore, the intergradation of rimmed and non-rimmed pits on some calyces strongly suggests that both types were produced by a single kind of epizoan. Rims appear to have formed by a process very similar to that which produced tubercles belonging to the normal plate ornament in this species (i.e. secondary secretion). In some instances the rims appear to grade laterally into such tubercles.

Pits in Eucalyptocrinites appear never to occur on the free arms. However, the specialized tegmen partition plates which lie between the arms of Eucalyptocrinites were frequently infested. In some specimens each of the ten plates bears a row of $0.5-1.0 \mathrm{~mm}$ pits, but none occur on the intervening arms (Fig. 7). In several instances, holes lying along the margin of partition plates 

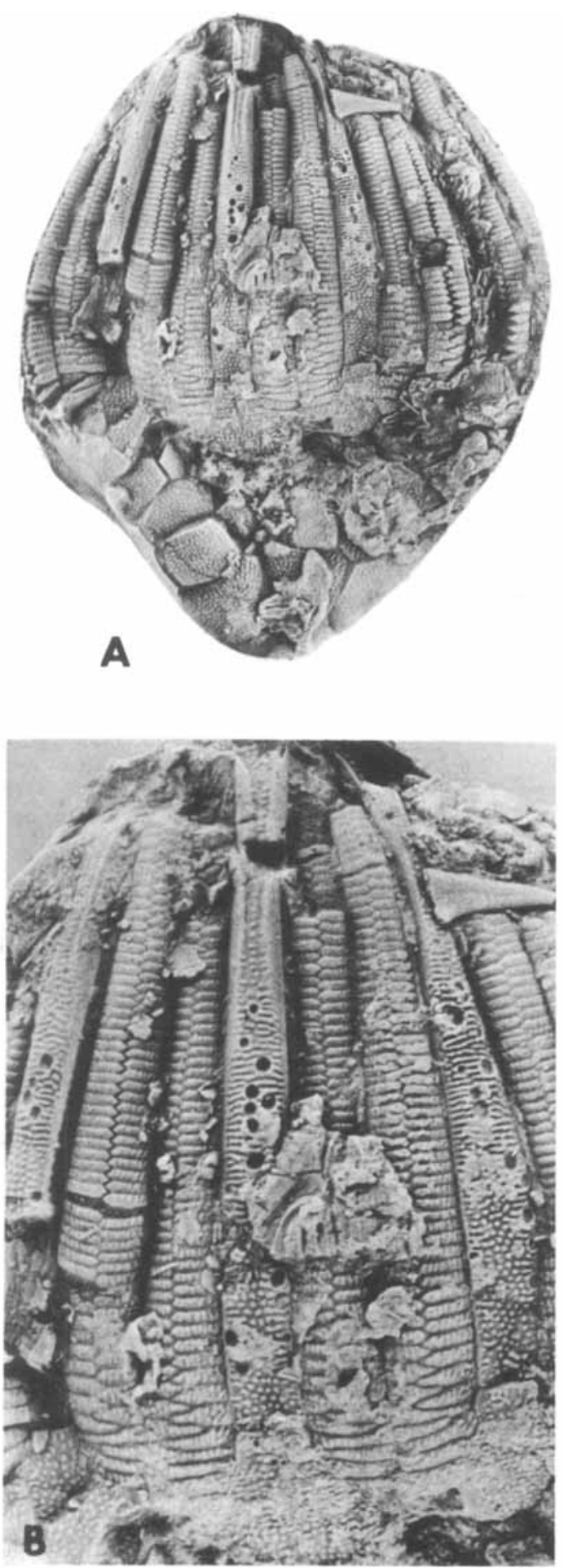

Fig. 7. Circular pits in the tegmen partition plates of Eucalyptocrinites caelatus (Hall); Rochester Shale, Middle- are truncated abruptly at this surface and do not continue onto the immediately adjacent arm.

The surfaces of brachial plates in Eucalyptocrinites may have been kept free of epizoan attachment due to the mobility of the arms. However, the occurrence of pits on the immediately adjacent partition plates presents a problem. In each of eight specimens of Eucalyptocrinites caelatus exhibiting this phenomenon, the distribution of pits on the partition plates is quite similar. Pits occur only on the lower two thirds of the plates, terminating at roughly the same height on each plate of a given specimen (Fig. 7B). Since this upper limit of the pits occurs at a homologous position on crowns of different size, this break cannot be explained as the result of growth in a particular individual.

Living comatulid crinoids utilize the pinnules to sweep the calyx and portions of the cirri free of debris (D. B. Macurda, Jr., personal communication). Parts of the cirri which are beyond the reach of the pinnules are frequently encrusted with organisms. These observations provide an analogy for the distribution of pits on Eucalyptocrinites. The proximal pinnules of Eucalyptocrinites are quite long (between $1 / 3$ and $2 / 3$ the height of the partition plates) and are directed upwardly at an angle of about $45^{\circ}$ to the main arm. Unless they could have been rotated back almost $180^{\circ}$, the tips of these pinnules could not have touched the lower parts of the partition plates. In contrast, the upper (more distal) portions of the partitions could have been swept readily by the free ends of distal pinnules when the arms were extended for feeding. These areas are notably free of pits.

Aside from the raised rims mentioned previously, deformation associated with the pits is generally slight in Eucalyptocrinites. However, one specimen of Eucalyptocrinites caelatus exhibits a wart-like protuberance of swollen stereom surrounding two $1.8 \mathrm{~mm}$ adsutural pits (Fig. 8). The gall and associated pits seem fundamentally different from the simple small pits observed in other specimens of Eucalyptocrinites and the deformation may have been produced by a different epizoan type. However,

port, Niagara Co., N.Y. BMS E23974. $\square$ A. View of entire crown showing restriction of pits to tegmen partition plates; $\times 1.4$. $\square$ B. Enlargement of upper crown, note strong alignment of pits and termination of pits at nearly equal heights on each partition plate and complete absence of these holes on adjacent arms; $\times 2.8$. 

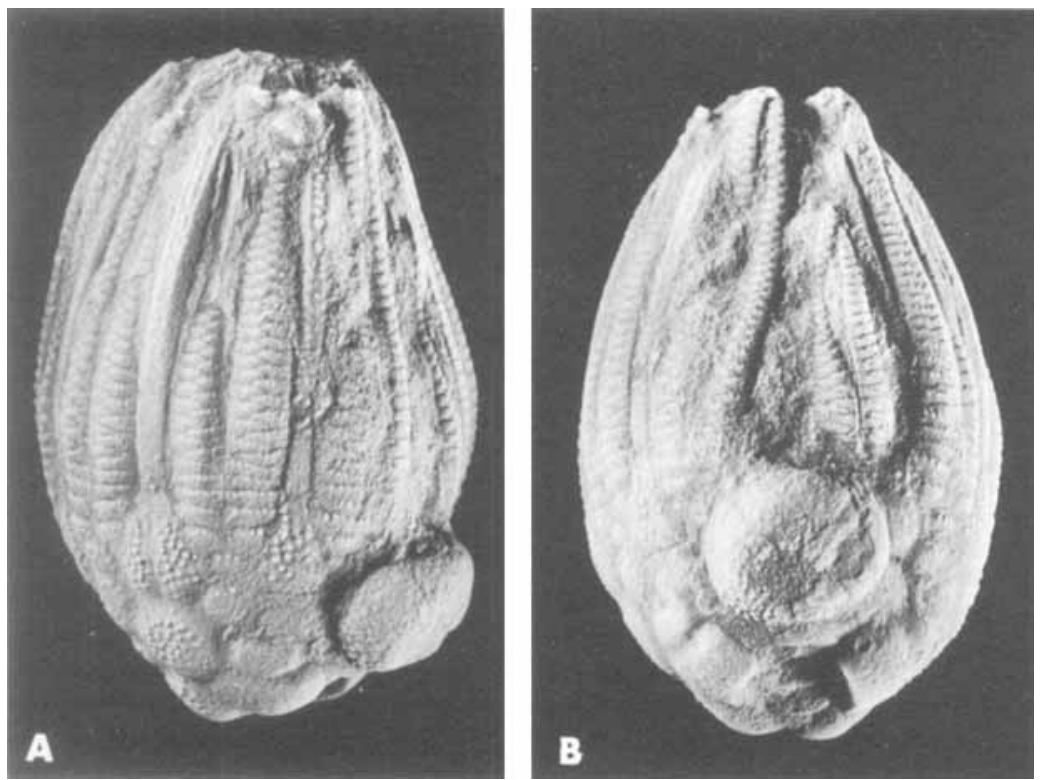

Fig. 8. Crown of Eucalyptocrinites caelatus (Hall) exhibiting capsule-like stereomic swelling surrounding two pits; middle Rochester Shale, Highway 406 roadcut, Niagara Escarpment,

Thorold, Ontario. $\square$ A. View of specimen showing lateral profile of swelling. $\square$ B. Specimen rotated showing two non-overlapping pits on the gall (pits lightly shaded to accentuate form): granulose ornament and plate sutures continue from unaffected area onto swelling: ROM 35651 , J. D. Eckert Collection; both $\times 2$

this may merely represent an extreme example of reaction of the host against infesting epizoans. The gall shows tuberculate ornament similar to that of surrounding, undeformed plate surfaces, suggesting deformation by thickening of primary plate stereom rather than a secondary stereomic secretion. The crinoid specimen is small (calyx height $21 \mathrm{~mm}$ ), while the pits are relatively large, indicating that the epizoans settled on the host during the period of early active growth of the plates (normal maturation) and so had a pronounced effect on the primary development of the plates. Other, larger, Eucalyptocrinites specimens which have been affected do not exhibit such major malformations of the plates. Pits may have been initiated after primary plate growth was largely, though not entirely, completed; thus they had a lesser effect.

Type 4. - Host species: Asaphocrinus ornatus (Hall), and Lecanocrinus macropetalus Hall (Fig. 9). Asaphocrinus ornatus was also subject to infestation by pit-forming epizoans (Table 1). About a fifth of the specimens examined bear circular depressions on the calyx plates. These depressions exhibit a similarly wide range of diameters as those occurring on Ichthyocrinus laevis. The smallest $(0.5-1.0 \mathrm{~mm})$ pits are parabolic and essentially indistinguishable from minute pits occurring in other crinoids. However, the larger holes are distinctly different from the latter and from other types discussed herein. They are shallow $(1.0-4.0 \mathrm{~mm})$ depressions (depth/diameter ratio approximately 1:6) with slightly irregular floors. The most diagnostic feature of the large pits in Asaphocrinus is the presence, in many of the larger depressions, of a faint inner ring concentric with the outer border of the pit and about $0.5-0.8 \mathrm{~mm}$ in from the margin toward the center of the hole (Fig. 9). This inner ring is usually incomplete, and appears to be lacking in smaller pits, but has been observed in the majority of the larger holes. Because of their intergradation on single calyces, small and large pits on Asaphocrinus are thought to represent domichnia (habitation traces) of individuals of different size belonging to a single epizoan type.

In specimens of Asaphocrinus examined to date, pits have been observed only on the base of the calyx, typically straddling sutures between plates (Fig. 9B). Generally, there appear to be fewer pits per calyx area in Asaphocrinus than in Ichthyocrinus or Eucalyptocrinites. Two or three pits per calyx is typical, the maximum observed number being seven. Pits tend to be clustered and, in some cases, show slight overlap.

Lecanocrinus puteolus Ringueberg (1886:11, P1. 1:8) is one of two proposed species of Rochester crinoids which was incorrectly established on the basis of circular pits (supposed 

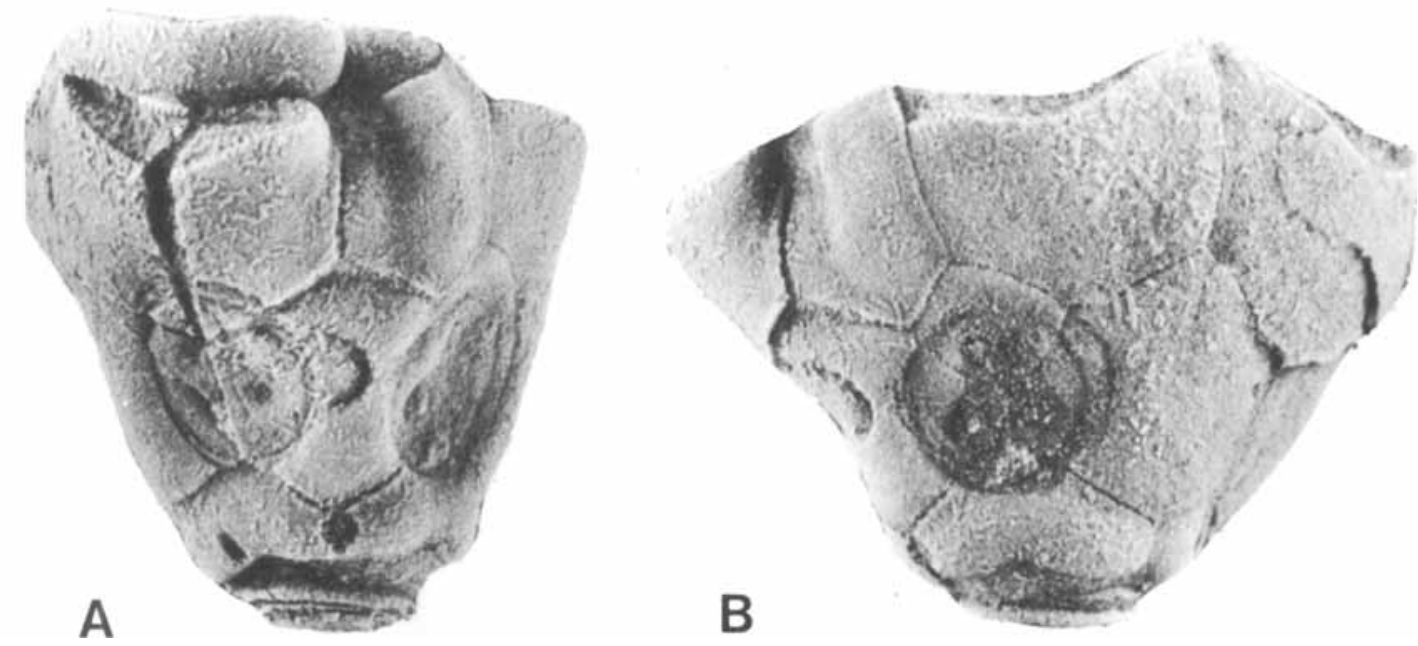

Fig. 9. Pits in Asaphocrinus ornatus (Hall); lower Rochester Shale, DeCew Falls, St. Catharines, Ontario. $\square$ A. DE-interray view of calyx showing five pits; note overlap between large and small holes near center of specimen. $\square$ B. CD-interray view of same; note extreme shallowness of pits, and inner rims; ROM 35801 ; both views $\times 6$.

ornamentation) on the plates (Eucalyptocrinites papulosus has been discussed previously). The holotype of $L$. puteolus (synonymized by Springer 1920:129) is a specimen of Lecanocrinus macropetalus bearing five depressions of subequal diameter on the plates. This is one of only two specimens from a total of over 200 calyces of Lecanocrinus which shows pits of the same type as those in Asaphocrinus (circular with somewhat vague outlines and quite shallow); thus Lecanocrinus was only rarely affected.

Summary. - Circular pits of distinct morphologies occur commonly in five relatively uncommon species of crinoids from the Rochester Shale, and very rarely in two others. Table 2 summarizes the contrasting characteristics of the various pit types discussed in the preceding section. In general there is a close correspondence between the morphology and mode of occurrence of pits, and the species of crinoid in which they occur. In part, at least, the observed differences may be due to variations in the reaction of host tissues to the presence of the holeproducing agents. Thus, for example, the rims of stereom surrounding pits of some Eucalyptocrinites specimens may not have been characteristic of the epizoan, but rather represent a reaction of the host stereom. Some Eucalypto- crinites individuals reacted to the epizoan and secreted such rims around them while other crinoids did not do so.

On the other hand, characteristics such as the location, size range, and spacing of pits, the occurrence of overlap between holes, and markings on the floor of the pit (in Asaphocrinus), appear to reflect the behavior and morphology of the pit-producers themselves. Since substantially different combinations of these features are characteristic of pits occurring in different crinoid species, it is likely that they were the work of different though perhaps related species of epizoans. This further stresses the specificity of the occurrence: not only were parabolic pits restricted to certain species of crinoids, different crinoids were perhaps host to distinct species of epizoic pit-forming organisms.

This latter hypothesis is also supported by indirect evidence. It was noted in the preceding section that in the Homocrinus bed at Lockport, N.Y., non-infested Ichthyocrinus laevis was commonly associated with infested Asaphocrinus ornatus. This situation might be explained by the assumption that the symbionts of Asaphocrinus were present while those of Ichthyocrinus were not, or, alternatively, that Asaphocrinus was the preferred host. In either case host-selection is indicated; present evidence favors the first alternative. 
Table 2. Summary chart of morphological and distributional characteristics of circular-parabolic pits occurring on species of crinoids from the Rochester Shale. $\mathbf{N}=$ total number of pits measured.

$\begin{array}{lll}\text { Crinoid host species } \mathrm{N} & \frac{\text { Pit diameter (mm) }}{\text { Range Mean S.D. }} & \begin{array}{l}\text { Max. no./Depth/ Comments and special features } \\ \text { calyx diameter }\end{array}\end{array}$

$\begin{array}{llllllll}\begin{array}{l}\text { Ichthyocrinus } \\ \text { laevis Conrad }\end{array} & 529 & 0.1-3.6 & 0.95 & 0.65 & 100+ & 0.9 & \begin{array}{l}\text { little associated deformation; pits of differing size } \\ \text { frequently overlap riddling large areas of calyces; } \\ \text { some plate thickening in vicinity of pits }\end{array}\end{array}$

\section{Synchirocrinus?} typus (Ringueberg) calceocrinid n.sp.

Eucalyptocrinites spp.

\section{Asaphocrinus} ornatus (Hall)

Lecanocrinus

macropetalus Hall

$\begin{array}{rrrrrrr}42 & 0.5-2.0 & 1.39 & 0.42 & 20 & 1.0 \\ 124 & 0.2-1.8 & 0.69 & 0.16 & 80+ & 1.0 \\ 22 & 0.5-4.0 & 1.61 & 0.99 & 7 & 0.2\end{array}$

\section{Nature of the relationship}

Reaction of the crinoids to activities of the holeproducing epizoans, and the restriction of infestation to specific locations on the crowns (particularly in Eucalyptocrinites) provide evidence that in many cases the crinoid hosts were living at the time the pits were produced (cf. Rodriguez \& Gutschick 1975). Evidence of hostselection by the pit-formers further implies dependence of the epizoans on the crinoid hosts. The organisms evidently utilized their hosts' skeletons as a hard substrate to settle on. Growth of the crinoid stereom may also have been advantageous in facilitating embedment of the epizoans in sheltered pockets.

Dependent relationships between modern organisms include parasitism, mutualism, predation, and some examples of commensalism (Lawrence 1971). It is very improbable that crinoids ever benefited from the activities of pit-forming epizoans; thus mutualism is rejected as a possible interpretation in this case. Likewise, the hole producers were almost certainly not predaceous upon the crinoids, since very few holes penetrate through the plates into the visceral cavity of the echinoderms (only observed in two specimens of Ichthyocrinus). Furthermore, the general absence of pits from the arms of crinoids indicates that the epizoans did not normally utilize their host's food supply. Crinoid stereom contains up to $50 \%$ pore area (Macurda \& Meyer 1975) which during life is filled with mesodermal tissue (stroma). It is possible that an epizoan could derive some nutrition from this tissue. At present this hypothesis seems unlikely and is unsupported by modern evidence, but it cannot be ruled out.

Since it is impossible to determine whether or not the epizoans derived any food from their hosts, the co-action cannot be classified as parasitism in the restricted sense used by most recent workers (e.g. Hopkins 1957; Pianka 1974). In specific examples, the relationships between the epizoans and the crinoids do seem to fit somewhat broader definitions of parasitism such as that of Odum (1971), since they represent dependent co-action pairs in which the host was harmed. The epizoans clearly had a damaging effect on some crinoids, as in cases where holes penetrate through calyx plates or riddle portions of crinoid calyces (Fig. 2A, B). Reactions of crinoids to the epizoans also suggest that the relationship was not always completely passive. On the other hand, the damage done by pitformers in most cases was relatively minor and the effect on their hosts probably neutral. The more adverse effects were incidental and rare. Thus, the co-action is presently viewed as an example of a dependent commensal relationship (sensu lato), perhaps bordering on parasitism in some cases.

Ecological control of host-selection is not obvious. The several affected crinoid species had widely differing life modes, trophic positions, and morphologies. As noted previously they are neither the most abundant nor the largest members of Silurian crinoid assemblages. Further- 
more, they include members of three different subclasses. Thus, the causes of host selectivity are subtle and are probably linked to lengthy periods of co-evolution between the epizoans and their hosts (see below).

Larval selection of substrates has been documented in numerous studies of Recent invertebrates (Thorson 1950; Wilson 1952). In many cases larvae appear to respond to chemical stimuli in choosing substrates for settlement. Settlement of epizoans on the surface of a crinoid endoskeleton requires biochemical compatibility between the epizoan and the host epidermis. Secretions of the epidermis may have inhibited settlement by pit-forming epizoans on many (most) Paleozoic crinoids. Other species lacking such biochemical defenses would have been susceptible to infestation by at least some species of hole-forming epizoans. It is also possible that some crinoids produced substances that actually attracted epizoans.

Once established on a particular crinoid species, epizoans could have adapted to minor changes in the host's biochemistry. Thus, pitformers could co-evolve with their hosts until the crinoids either underwent radical changes of epidermis biochemistry or became extinct.

\section{Circular-parabolic pits in other Silurian crinoid faunas}

The high degree of host-selectivity apparent in pit-forming epizoans on crinoids from the Rochester Shale is also reflected in other crinoid faunas. One might predict that related species in contemporaneous crinoid faunas of different geographic areas would have been hosts to similar epizoans. Surveys of several Silurian crinoid faunas aside from the Rochester Shale assemblages suggest that this is the case.

The Gasport Limestone (upper Wenlockian, Lockport Group; western New York, Ontario) contains a diversity of crinoid and cystoid species, clearly related to those of the older Rochester Shale faunas. Thirteen species of pelmatozoans have recently been obtained from the Gasport at Thorold, Ontario (James D. Eckert, personal communication). Thus far, circular-parabolic pits have been observed only in the dorsal cups of Ichthyocrinus conoideus Ringueberg, and Asaphocrinus sp. from this locality. The size range, distribution, and morphology of the pits in Ichthyocrinus conoi- deus resemble those described previously for the closely related species I. laevis. Among specimens from the Gasport Limestone at Lockport, N.Y., in the Springer Collection (U.S.N.M.) the author observed minute pits on two fragmentary specimens of Eucalyptocrinites sp.

The well-known Waldron crinoid faunas of Indiana and Tennessee have not yielded pitted Ichthyocrinus. However, small pits have been observed in an unidentified calceocrinid crinoid, and various dorsal cups of Eucalyptocrinites from Waldron, Indiana. Pitted Eucalyptocrinites specimens were also found among the Springer collections from the Brownsport Formation in Tennessee.

Wenlockian limestones of Gotland contain extremely diverse assemblages of crinoids (Bassler \& Moodey 1943 list over 200 Gotland species). At present, data on these assemblages are insufficient to determine to what degree the epizoans were host-specific, but illustrations of Gotland specimens suggest that they were. Springer (1920) figures numerous specimens belonging to 35 species of flexible crinoids from Gotland. His illustrations show pits in only three specimens, all of which belong to Ichthyocrinus. Two illustrated specimens of $I$. pyriformis (Phillips) bear relatively shallow, circular pits on calyx and brachial plates (Springer 1920, Pl. 32:11, 12; reproduced in Fig. 10, herein). Very similar pits are illustrated in a specimen of I. gotlandicus Wachsmuth \& Springer (Springer 1920, P1. 35:12). While the pits occurring on the Gotland forms differ slightly from those on Ichthyocrinus laevis from North America, they appear more similar to the latter than to the other pit types discussed in the present paper.

Franzén (1974:289, Fig. 1C) discusses and illustrates the occurrence of pits in the spines of Calliocrinus from the Högklint Beds of Gotland. The size and spacing of the pits are similar to those of holes on Eucalyptocrinites. It is noteworthy that Calliocrinus and Eucalyptocrinites have been united in the family Eucalyptocrinitidae (Moore \& Laudon 1943). Franzén (1974, Fig. 6) also illustrates the pitted and severely deformed crown and proxistele of another crinoid, not identified in the figure description, but probably belonging to the genus Clonocrinus (Christina Franzén, personal communication). Clonocrinus is considered to be ancestral, or closely related, to crinoids of the Eucalyptocrinitidae (Moore \& Laudon 1943).

Aside from these examples few pitted calyces 

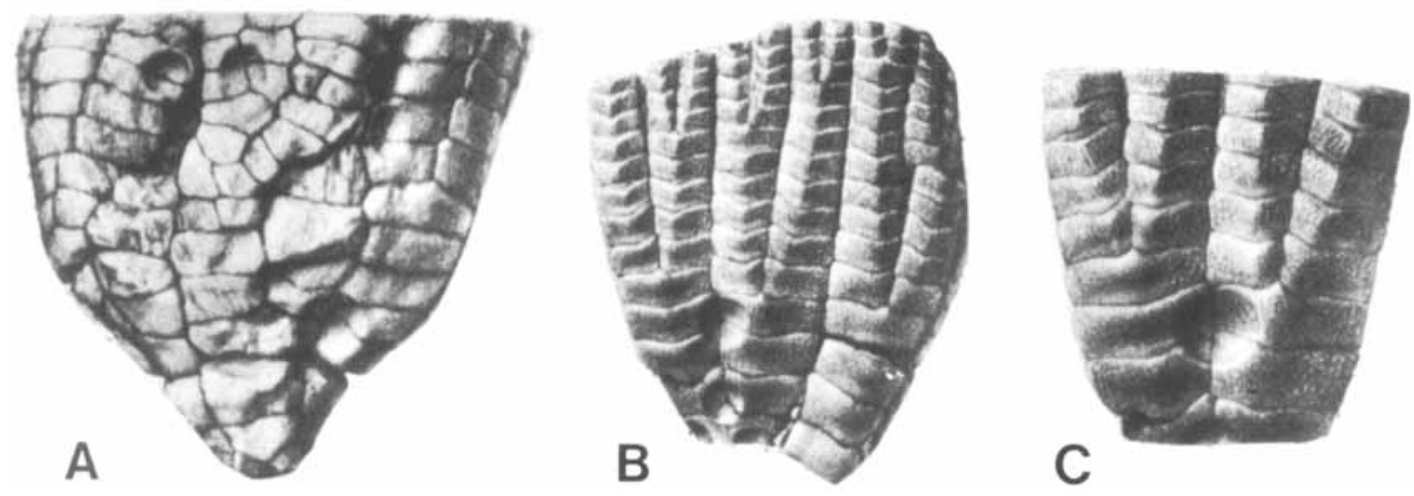

Fig. 10. Circular-parabolic pits in Ichthyocrinus pyriformis (Phillips). Wenlockian. Fårö, Gotland. $\square$ A. Anterior view of a crown exhibiting large, rather shallow pits on the calyx and brachials; $\times 2.4$. $\square$ B. Fragmentary specimen with pits on brachial plates; $\times 2.4$. $\square$ C. Same: $\times 3.5$. (From Springer 1920, Pl. 32:11b, 12a, b.)

of Gotland crinoids have been illustrated. Bather (1893, Pl. 6:175, 176; Pl. 7:202) figures pits in Botryocrinus ramosus (Angelin), and Cyathocrinites monilifer (Angelin). A partial calyx with numerous small pits illustrated by Franzén (1974, Fig. 4) was identified as Crotalocrinites pulcher (Hisinger) on the original label, although this identification is in doubt.

Thus, within several Late Silurian crinoid faunas, pits seem to be restricted to a limited number of taxa. The affected species in most cases belong to the same genus (e.g. Ichthyocrinus) or to related genera (e.g. Eucalyptocrinites, Calliocrinus, Clonocrinus). The morphology of pits occurring in related crinoids is also fairly consistent. For example, small usually non-overlapping holes characterize Eucalyptocrinites and Calliocrinus, while pits of variable size which frequently intersect are typical of Ichthyocrinus.

\section{Co-evolution of host-epizoan pairs}

Comparison of various instances of pitted crinoids in post-Silurian assemblages provides evidence that the producers of the circular pits co-evolved with their crinoid hosts for extensive time-spans. Pits observed in a specimen of Synaptocrinus nuntius (Hall) from the Middle Devonian Hamilton Group of western New York are very similar to those found in the Silurian Ichthyocrinus. Synaptocrinus is assigned to the Ichthyocrinidae and is thought to have descended from Ichthyocrinus (Moore \& Laudon 1943).
Somewhat shallower holes (intermediate between those observed in Ichthyocrinus and those of Asaphocrinus) have also been observed in other flexible crinoid genera. Schmidt (1941, Pl. 25:1) illustrates a pitted specimen of Eutaxocrinus patulus Schmidt from the Middle Devonian of Germany. Significantly, ichthyocrinid crinoids are thought to have evolved from members of the Taxocrinidae in the Late Ordovician or Early Silurian. Large pits have also been observed in Euryocrinus laddi Stewart from the Middle Devonian of Ohio, a member of the Synerocrinidae which, in turn, may have been derived from ichthyocrinids or their immediate ancestors. Finally, holes similar to those of Euryocrinus also occur on specimens of Amphicrinus and Synerocrinus of Pennsylvanian age (personal observation). Both named genera are also members of the Synerocrinidae (Moore \& Laudon 1943). The occurrence of similar pits among members of the probable lineage, ClonocrinusEucalyptocrinites-Calliocrinus has been alluded to previously.

Evidently crinoid hosts and the pit-producing epizoans co-evolved through timespans of several million years. For example, similar epizoans infested ichthyocrinids from the Late Silurian to the Middle Devonian while members of the Synerocrinidae were hosts to pit-forming epizoans from the Devonian to Late Pennsylvanian times.

The origin of the pit-forming habit and of host selection by the epizoans has not been investigated. Thorough studies of Middle to Upper Ordovician crinoid assemblages might 
provide insights into this problem. However, preliminary surveys of Ordovician collections indicate that pits are rare in crinoids of this age. Pit-forming symbionts appear to have been abundant and widespread on Silurian crinoids (Ubaghs 1953). This was also a time of rapid diversification of many crinoids. Newly evolved lineages, particularly the various flexible crinoids, were subject to infestation by pitforming epizoans, possibly because they lacked the necessary biochemical defenses to ward off these organisms. Among Devonian crinoid assemblages examined (nearly all from North America), pits were found to be relatively rare and the number of affected species low. This may be due, in part, to the extinction of host lineages (e.g. Eucalyptocrinitidae, Ichthyocrinus); it may also reflect increased evolution of biochemical detractant substances. The Mississippian was, again, a time of adaptive radiation of crinoids (Moore 1952) and, again, circular pits are very common in some taxa notably, rather newly-appearing genera of camerate crinoids such as Platycrinites and Dichocrinus (personal observation) as well as in some older lineages.

Finally, modern crinoids are hosts to a variety of commensal and parasitic organisms including two groups of hole-forming parasites, myzostomid annelids and certain gastropods (see Graff 1884; Vaney 1913; A. H. Clark 1921; Fishelson 1974). However, these organisms do not provide any good analogs for the producers of circularparabolic pits on fossil crinoids. Such holes have not been recorded from post-Paleozoic crinoids and it is quite probable that the organisms responsible for these deformations became extinct along with their specific camerate, flexible, and inadunate crinoid hosts.

Acknowledgments. - The author thanks Frederick J. Collier (U.S. National Museum), Norman D. Newell (American Museum of Natural History), David L. Meyer (University of Cincinnati), Richard S. Laub (Buffalo Museum of Science), and Desmond Collins (Royal Ontario Museum) for making specimens available for study. James D. Eckert (University of Toronto) provided data on pitted crinoids from the Gasport Formation at Thorold, Ontario. The author benefited from discussions of this study with Edward J. Buehler (S.U.N.Y., Buffalo), George C. McIntosh (University of Michigan) and W. David Liddell (U.M.). Various versions of this manuscript were reviewed by Donald B. Macurda, Jr. (U.M.). Christina Franzén (Uppsala University) also reviewed the manuscript critically and offered several suggestions for its improvement. Portions of this study carried out during 1975 were funded by a grant from the Scott Turner Memorial Bequest, Department of Geology and Mineralogy, University of Michi- gan. Specimens illustrated in this paper are deposited in the Buffalo Museum of Science (BMS), the Royal Ontario Museum (ROM), and the American Museum of Natural History (AMNH).

\section{References}

Arendt, Yu. А. (Арендт, Ю. А.) 1961: О повреждениях морских лилий, вызванных Schizoproboscina. [On injuries in sea lilies, caused by Schizoprohoscina.] Пa.teomo.to`uческий Жvpнa.t 1961, 101-106.

Bassler, R. S. \& Moodey, M. W. 1943: Bibliographic and faunal index of Paleozoic pelmatozoan echinoderms. Geol. Soc. Am. Spec. Pap. 45.734 pp.

Bather, F. A. 1893: The Crinoidea of Gotland. Pt. I. The Crinoidea Inadunata. K. Sven. Vetensk. Akad. Handl. 25:2. 200 pp., 10 pls.

Bowsher, A. L. 1955: Origin and adaptation of platyceratid gastropods. Univ. of Kansas Paleont. Contr. Mollusca Art. 5.11 pp., 2 pls.

Branson, C. 1964: Traces of a shell-boring organism. Okla. Geol. Notes 24(7), 166-167.

Brett, C. E. 1972: Borings in crinoids from the Mid Silurian Rochester Shale. Geol. Soc. Am. Abstr. with Programs $4(1), 4$.

Bromley, R. G, 1970: Borings as trace fossils and Entobia cretacea Portlock, as an example. In Crimes, T. P. \& Harper, J. C. (eds.): Trace Fossils, 49-90. Seele House Press, Liverpool.

Brower, J. C. 1966: Functional morphology of Calceocrinidae with description of some new species. J. Paleontol. 40, 613-634.

Cameron, B. 1969: Paleozoic shell-boring annelids and their trace fossils. Am. Zool. 9, 689-703.

Chatterton, B. D. E. 1975: A commensal relationship between a small filter feeding organism and Australian Devonian spiriferid brachiopods. Paleobiology 1(4), 371-378.

Clark, A. H. 1921: Monograph of existing crinoids. U.S. Natl. Mus. Bull. 82. Pt. 2 (Parasites and Commensals), 616-660.

Clarke, J. M. 1908: The beginnings of dependent life. New York State Mus. Bull. 121, 146-169. 13 pls.

Clarke, J. M. 1921: Organic dependence and disease: their origin and significance. New York State Mus. Bull. 22I. 222, 1-113. 105 pls.

Dales, R. P. 1957: Interrelations of organisms: A. Commensalism. In Hedgepeth, J. W. (ed.): Treatise on marine ecology and paleoecology 1, 391-412. Geol. Soc. Am. Mem. 67.

Ehrenberg. K. 1929: Pelmatozoan root forms (fixation). Am. Mus. Nat. Hist. Bull. 59(1), 1-76.

Etheridge, R, 1880: Observations on the swollen condition of Carboniferous crinoid stems. Proc. Nat. Hist. Soc. Glasg. 9, 19-36.

Fay, R. O. 1962: The ventral structures of Stephanocrinus angulatus Conrad. J. Paleontol. 36, 206-2 10.

Fishelson, L. 1974: Ecology of northern Red Sea crinoids and their epi- and endozoic fauna. Mar. Biol. 26, 183-192.

Franzén. C. 1974: Epizoans on Silurian-Devonian crinoids. Lethaia 7, 287-301.

Franzén, C. 1977: Crinoid holdfasts from the Silurian of Gotland. Lethaia 10, 219-234.

Girty, G. H. 1915: Fauna of the Wewoka Formation of Oklahoma. U.S. Geol. Surv. Bull. 544.217 pp., 35 pls.

Graff, L. von 1884: Report on the Myzostomida collected during the voyage of $H . M . S$. Challenger during the years 
1873-1876. Report Sci. Results Voyage Challenger Zool. 10, $1-126$.

Graff, L. von 1885: Über einige Deformitäten an fossilen Crinoiden. Palaeontographica 31, 183-192.

Hall, J. 1852: Paleontology of New York. 2. Organic remains of lower middle division of the New' York system. 362 pp., 85 pls. Albany, N.Y.

Halleck, M. S. 1973: Crinoids, hardgrounds, and community succession: the Silurian Laurel-Waldron contact in southern Indiana. Lethaia 6, 239-252.

Häntzschel, W. 1975: Trace fossils and problematica (1st supplement). In Moore, R. C. (ed.): Treatise on Invertebrate Paleontology. W (2nd ed.), Miscellanea. Geol. Soc. Am. and Univ. Kansas Press.

Hopkins, S. H. 1957: Interrelations of Organisms: B. Parasitism. In Hedgepeth, J. W. (ed.): Treatise on marine ecology and paleoecology. 1, 413-428. Geol. Soc. Am. Mem. 67

Howell, B. F. 1962: Worms. In Moore, R. C. (ed.): Treatise on Invertebrate Paleontology, W, Miscellanea, 144-177. Geol. Soc. Am. and Univ. Kansas Press.

Korringa, P. 1951: The shell of Ostrea edulis as a habitat: observations on the epifauna of oysters living in Oosterschelde, Holland, with some notes on polychaete worms occurring there in other habitats. Arch. Néerl. Zool. 10 (for 1954), 32-152.

Lawrence, D. R. 1971: The nature and structure of paleoecology. J. Paleontol. 45(4), 593-607.

Macurda, D. B., Jr. \& Meyer, D. L. 1975: The microstructure of the crinoid endoskeleton. Univ. Kansas Paleontol. Contr., Pap. 74, 1-22.

Moodie, R. L. 1918: On the parasitism of Carboniferous crinoids. J. Parasitol. 4, 174-176.

Moore, R. C. 1952: Evolution rates among crinoids. J. Paleontol. 26(3), 338-352.

Moore, R. C. \& Laudon, L. R. 1943: Evolution and classification of Paleozoic crinoids. Geol. Soc. Am. Spec. Pap. 46, $1-153$.

Moore, R. C. \& Plummer, F. B. 1940: Crinoids from the upper Carboniferous and Permian strata in Texas. Texas Univ. Publ. 3945, 468 pp., 21 pls.

Odum, E. P. 1971: Fundamentals of Ecology. 546 pp. W. B. Saunders Co., Philadelphia.

Pianka. E. R. 1974: Evolutionary Ecology. 356 pp. Harper \& Row, New York, Evanston, San Francisco, London.

Raup, D. M. 1966: The endoskeleton. In Boolootian, R. A. (ed.): Physiology of Echinodermata, 379-395. Interscience, New York.

Richards, R. P. 1974: Ecology of the Cornulitidae. J. Paleontol. 48(3), 514-523.

Ringueberg, E. N. S. 1886: I. New genera and species of fossils from the Niagara shales, Buffalo Soc. Nat. Sci. Bull. 5(I), 1-22.

Ringueberg, E. N. S. 1888: Niagara shales of western New York; a study of the origin of their subdivisions and faunae. Am. Geol. 1, 264-272.

Rodriguez, J. \& Gutschick, R. C. 1975: Epibiontic relationships on a Late Devonian algal bank. J. Paleontol. 49(6), $1112-1120$.

Schmidt, W. E. 194 I : Die Crinoideen des Rheinischen Devons. II. Teil: Die Crinoideen des Unterdevons bis zur Cultrijugatus-Zone. Abh. Reichsstelle f. Bodenforschung, N.F. Heft 182, 1-253.

Springer, F. 1920: Crinoidea Flexibilia. Smithson. Inst. Publ. 2501, 486 pp., 86 pls.

Strimple, H. L. 1963: Crinoids of the Hunton Group. Okla. Geol. Surv. Bull. 100. 169 pp., 12 pls.

Thayer, C. W. 1974: Substrate specificity of Devonian epizoa. J. Paleontol. 48(5), 881-894.

Thorson, G. 1950: Reproduction and larval ecology of marine bottom invertebrates. Biol. Rev. 25, 1-45.

Ubaghs, G. 1953: Classe des Crinoides. In Piveteau, J. (ed.): Traité de Paleontologie 3, 658-773.

Vaney, C. 1913: L'adaptation des gastropodes au parasitisme. Bull. Scient. de la France et de la Belgique 47, 1-87.

Wachsmuth, C. \& Springer, F. 1897: North American Crinoidea Camerata. Harv. Coll., Mus. Comp. Zool. Mem. 20, 21, 22. 897 pp., 83 pls.

Warn, J. M. 1974: Presumed myzostomid infestation of an Ordovician crinoid. J. Paleontol. 48(3), 506-513.

Welch, J. R. 1976: Phosphannulus on crinoid stems. J. Paleontol. 50(2), 218-225.

Wilson, D. P. 1952: The influence of the nature of the substratum on the metamorphosis of the larvae of marine animals, especially the larvae of Ophelia bicornis Savigny. Inst. Oceanog. Monaco, Ann. 27, 49-156.

Yakovlev, N. N. 1939: On the discovery of an original parasite on a marine crinoid from the Carboniferous. Dokl. Akad. Nauk SSSR. 22(3), 146-148.

Yonge, C. M. 1957: Interrelations of organisms: C. symbiosis. In Hedgepeth, J. W. (ed.): Treatise on marine ecology and paleoecology. 1, 429-442. Geol. Soc. Am. Mem. 67. 